\title{
PERBAIKAN KUALITAS AIR BAKU OLEH ISOLAT BAKTERI NITRIFKASI INDIGENOUS MENGGUNAKAN MOVING BED BIOFILTER REACTOR (MBBR)
}

\section{RAW WATER QUALITY IMPROVEMENT BY INDIGENOUS NITRIFYING BACTERIA ISOLATES USING MOVING BED BIOFILTER REACTOR (MBBR)}

\author{
Ramiza Dewaranie Lauda, Suprihatin*), dan Titi Candra Sunarti \\ Program Studi Teknologi Industri Pertanian, Sekolah Pascasarjana IPB University \\ Kampus IPB Darmaga, PO Box 220 Bogor 16002, Indonesia \\ Email: \\ Makalah: Diterima 27 Agustus 2018; Diperbaiki 27 Juni 2019; Disetujui 10 Juli 2019
}

\begin{abstract}
Bio-filtration technology is considered as one of prevention solutions for declining raw water quality. The research purpose was to identify biofilm growth formation as viability cell in acclimatization period that can be used for ammonia elimination by using various indigenous chemo-heterotroph bacteria isolated from biofilter media specimen and moving bed bio-filter reactor performance. Reactor was configured within aerobic system comparing two biofilm-attached support-medium filters (i.e. drinking-water-bottle-PET-chips and PVC). Bacteria potency on ammonia removal in kinetics modeling was advance investigated. Kinetics determination was based on empirical approach in first order by using formula of $C_{\text {out }}=C_{\text {in }} \exp (-k . E B R T)$, where $C_{\text {out }}$ is ammonia concentration in outlet, $C_{\text {in }}$ is ammonia concentration in inlet, $k$ is first-order reaction rate constant and Empty Bed Retention Time (EBRT) can be formulated about setting comparison the discharge ammonia load $(Q)$ and volume reactor $(V)$. Total thirteen potential biofilm bacterias were successfully isolated in 24-hoursincubation at $37^{\circ} \mathrm{C}$ and by using Bergey's method successfully identified prime biofilm isolates of Bacillus sp and Pseudomonas sp, then re-selected to determine one with the best ammonia removal ability. The ammonia removal kinetics constant of each reactor was obtained as followed: (1) $k_{P E T}=0.421 h^{-1}\left(\eta=62.47 \%-\mathrm{NH}_{3}\right)$ and (2) $k_{P V C}=0.412 h^{-1}\left(\eta=58.80 \%-\mathrm{NH}_{3}\right)$.
\end{abstract}

Keywords:ammonia removal, biofilm viability, bio-filtration, raw water, polyethylene terephthalate chips

\section{ABSTRAK}

Teknologi bio-filtrasi merupakan salah satu usaha teknologi pencegahan penurunan kualitas air baku. Penelitian ini bertujuan untuk mengidentifikasi pola pertumbuhan biofilm sebagai jumlah sel hidup yang diperoleh selama periode aklimatisasi, sehingga dapat digunakan dalam proses eliminasi amonia oleh beberapa jenis bakteri indigenous jenis kemo-heterotrof. Bakteri tersebut berhasil diisolasi dari spesimen media bio-filter selama pengukuran kinerja moving bed bio-filter reactor. Konfigurasi reaktor dirancang menggunakan sistem aerobik dengan memanfaatkan dua jenis media pendukung untuk penempelan biofilm (botol plastik minuman PET chips dan PVC). Potensi bakteria dalam penyisihan amonia dilakukan investigasi lanjutan menggunakan pemodelan kinetika. Kinetika mengikuti pendekatan empiris orde pertama menggunakan formula $\mathrm{C}_{\text {out }}=\mathrm{C}_{\mathrm{in}} \exp (-$ k.EBRT), dimana $\mathrm{C}_{\text {out }}$ merupakan konsentrasi amonia di outlet, $\mathrm{C}_{\mathrm{in}}$ adalah konsentrasi amonia di inlet, $\mathrm{k}$ adalah konstanta kinetika dan Empty Bed Retention Time (EBRT) dengan merumuskan dari perbandingan laju alir umpan (Q) terhadap volume reaktornya (V). Total 13 koloni isolat indigenous biofilm berhasil diisolasi selama 24 jam-inkubasi $37^{\circ} \mathrm{C}$, dan menggunakan metode Bergey berhasil didefinisikan enam isolat terbaik sebagai Bacillus sp dan Pseudomonas sp, kemudian diseleksi kembali untuk mendapatkan isolat unggul dalam penyisihan amonia. Konstanta kinetika penyisihan amonia pada masing reaktor secara berturut : (1) $\mathrm{k}_{\mathrm{PET}}=$ $0,421 \mathrm{jam}^{-1}\left(\eta=62,47 \%-\mathrm{NH}_{3}\right)$ dan $(2) \mathrm{k}_{\mathrm{PVC}}=0,412 \mathrm{jam}^{-1}\left(\eta=58,80 \%-\mathrm{NH}_{3}\right)$.

Kata kunci : amonia, biofilm, bio-filtrasi, air baku, moving bed biofilter reactor

\section{PENDAHULUAN}

Air bersih sebagai sumber kehidupan mulai menghadapi permasalahan persediaan yang terbatas dan kualitas yang semakin menurun akibat cemaran hasil kegiatan manusia, sehingga semakin sulit untuk mendapatkan akses air bersih. Akibat penurunan kualitas air, terutama pada sumber-sumber air baku seperti air sungai yang dipergunakan dalam proses pengolahan air. Padahal air sungai dimanfaatkan sebagai sumber air baku tersebut dimanfaatkan kembali dalam produksi air bersih. Terjadinya penurunan kualitas air baku menyebabkan peningkatan biaya produksi untuk pengolahan air baku menjadi air bersih yang semakin mahal, sehingga akan berimplikasi kepada pelayanan penyediaan air bersih bagi masyarakat yang menjadi tidak maksimal, karena tidak memenuhi tentang Persyaratan Kualitas Air Baku (PPRI, 2001). Upaya yang dilakukan oleh perusahaan air bersih agar 
pelayanan air bersih untuk masyarakat dapat tetap berlangsung adalah dengan menggunakan klor untuk mereduksi mikroorganisme (disinfektasi) dan penggunaan filter karbon aktif dalam teknologi pengolahan lanjut (advanced treatment). Cara ini dapat meningkatkan kualitas olahan air baku, namun disisi lain menambah beban biaya pengolahan. Berdasarkan hasil survei BPS (2017) diperoleh data akses sumber air minum yang layak di Indonesia pada provinsi yang padat penduduk seperti Bali, DKI Jakarta, Riau, Kalimantan Utara, dan Kalimantan Timur mulai mengalami penurunan. Penurunan paling signifikan terjadi untuk provinsi DKI Jakarta yaitu $92,44 \%$ menjadi $88,93 \%$ akibat pencemaran sumber air baku .

Penelitian Lopez-Ponnada et al. (2017) dan Krishnan et al. (2008) merumuskan beberapa substrat berupa kontaminan (amonia) akan memberikan efek toksik sehingga konsorsium mikroba biofilm terhambat pertumbuhannya atau mati. Suprihatin et al. (2013) menggunakan biofiltrasi sebagai upaya peningkatan kualitas air baku didasarkan pada langkah antisipasi permasalahan buruknya kualitas air baku dengan solusi teknologi yang lebih ramah lingkungan. Mekanisme proses pelekatan biofilm mikroba indigenous pada medianya disebut aklimatisasi. Aklimatisasi (Spigno et al., 2003) merupakan upaya penyesuaian fisiologis oleh suatu organisme terhadap lingkungan baru yang akan dilewatinya, sampai kondisi pertumbuhannya steady state (tunak).

Agar diperoleh kualitas air baku yang mendekati standar air baku di Indonesia (PPRI, 2001), maka penelitian ini bertujuan untuk melakukan: (1) mengidentifikasi pola pertumbuhan biofilm sebagai jumlah sel hidup yang diperoleh selama periode aklimatisasi, sehingga dapat digunakan dalam proses eliminasi amonia oleh beberapa jenis bakteri indigenous jenis kemoheterotrof. Bakteri diperoleh dari tahapan isolasi dan karakterisasi spesimen media bio-filter selama pengukuran kinerja moving bed bio-filter reactor. Isolat bakteri nitrifikasi indigenous dari biofilm yang diperoleh, akan digunakan untuk perbaikan kualitas air baku menggunakan Moving Bed Biofilter Reactor/MBBR, dan (2) mengkaji kandungan pengaruh pembebanan air baku melalui simulasi laju alir dan amonia berdasarkan pendekatan empiris.

\section{METODE PENELITIAN}

\section{Karakterisasi Air Baku dan Perancangan Reaktor Biofilter MBBR \\ Air baku diambil dari intake Water Treatment Plant/WTP Sungai Cihideung yang sudah dilakukan screening dan settling sebelum masuk ke unit pengolahan air bersih. Karakterisasi air baku terdiri atas parameter kimia dan mikrobiologis}

mengikuti standar pengujian analisa kualitas air (APHA, 2012). Parameter yang dimonitoring adalah: parameter kimia $\left(\mathrm{COD}, \mathrm{NH}_{4}-\mathrm{N}, \mathrm{NO}_{3}-\mathrm{N}\right.$, fosfat) serta parameter mikrobiologis (total koliform dan Salmonella sp.). karakteristik air baku yang diperoleh dibandingkan mengacu pada standar air baku di Indonesia (PPRI, 2001; PPRI, 2015).

Reaktor yang digunakan merupakan reaktor biofilm tipe Moving Bed Biofilter Reactor/MBBR, dimana matriks filternya menggunakan jenis bahan berupa potongan botol plastik berbahan polyethylene-trepthalate/PET chips ukuran $5 \mathrm{~cm}^{2}$ dan Bioball yang menggunakan bahan plastik poly-vinylchloride/PVC. Reaktor didesain menggunakan sistem aerobik untuk memaksimalkan proses nitrifikasi air baku yang dialirkan masuk ke dalam MBBR oleh biofilm yang terbentuk pada matriks filternya (Gambar 1). Biofilm didapatkan dari tahapan aklimatisasi yang dilangsungkan selama 35 hari hingga mencapai kondisi steady-state yang ditandai kestabilan proses penyisihan kontaminan air baku serta kestabilan pertumbuhan sel biofilm. Selama proses aklimatisasi, reaktor MBBR dioperasikan menggunakan sistem kontinu untuk memudahkan penyesuaian debit air.

$$
\text { Stanbury dan Whitaker (1984) }
$$
menggunakan pendekatan dissolved oxygen/DO sebagai parameterkontrol sistem aerobik. Jika kurang dari critical dissolved oxygen (0,004-0,022 $\mathrm{mg} / \mathrm{L})$ akan menganggu proses metabolisme mikroba, maka aerasi dilakukan untuk pengoptimuman kinerja mikroba. Nilai DO pada outlet biofilter PET chips berada pada kisaran 4,7$6,2 \mathrm{mg} / \mathrm{L}$, sedangkan outlet biofilter PVC selama aklimatisasi berada pada rentang 4,9-5,3 mg/L.

\section{Isolasi, Seleksi, Karakterisasi Isolat Bakteri Nitrifikasi Indigenous Biofilm \\ Isolasi dan seleksi mikroba nitrifikasi} dilakukan dari biofilm indigenous yang menempel pada dua spesimen matriks PET dan PVC selama proses aklimatisasi. Isolasi tahap awal dilakukan pada media agar selektif umum meliputi Nutrient Agar (bakteri), PDA (kapang), YMEA (khamir), PCA (total mikroba) yang ditumbuhkan secara spontan selama 24 jam suhu $37^{\circ} \mathrm{C}$. Isolat yang didapat sebanyak 13 buah isolat, kemudian dilakukan seleksi menggunakan teknik enrichment (E) sebanyak tiga tahap pada kaldu amonia $\left(\mathrm{NH}_{4} \mathrm{Cl}\right) 1000$ ppm yang diberikan penambahan buffer phosfat dan phenol red pada beberapa rasio Nutrient Broth berbeda secara berturut-turut E1 $(0,8 \%$ b/v), E2 $(0,4 \%$ b/v), dan E3 $(0,2 \% \mathrm{~b} / \mathrm{v})$. Kemampuan nitrifikasi positif jika diperoleh perubahan warna kaldu dari kuning menjadi merah. Modifikasi metode isolasi diperoleh dari penelitian Harley dan Prescott (2002), Burrel et al. (2001) dan Welch et al. (2012). Modifikasi metode isolasi secara ringkas disajikan pada diagram alir Gambar 2. 


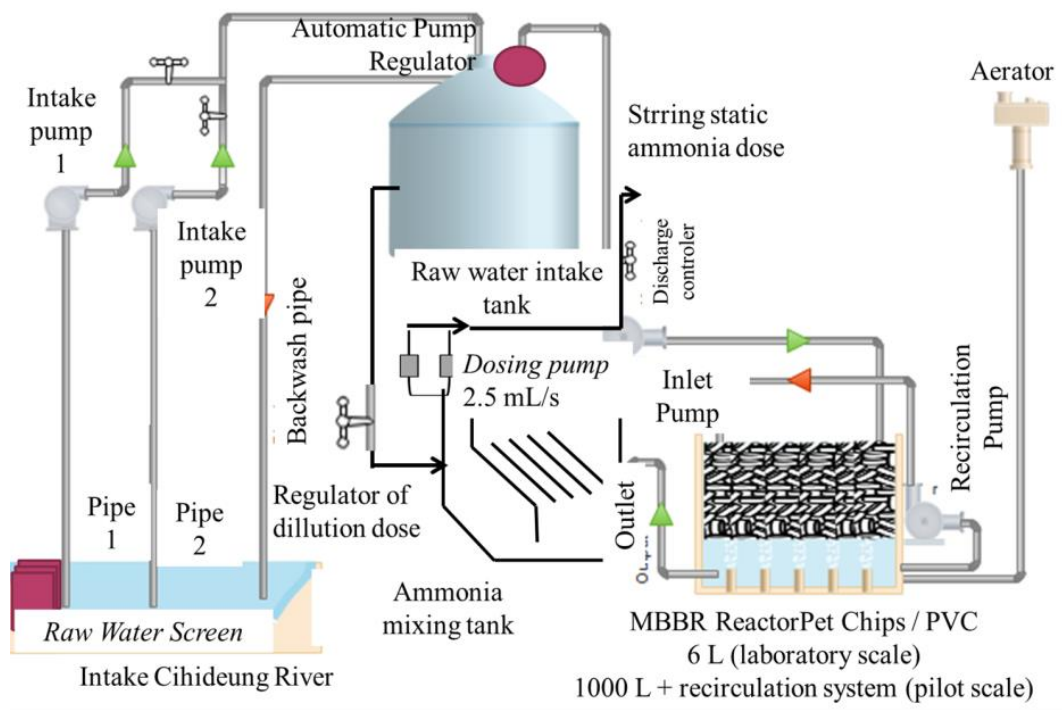

Gambar 1. Skema desain sistem pengolahan air baku menggunakan MBBR modus operasi kontinu aerobik. Terbagi dalam tiga tahapan utama : (a) proses penampungan air baku dari intake, (b) proses pembebanan amonia melalui pencampuran amonia dari tangki mixer, (c) proses MBBR secara aerobik pada yaitu skala lab untuk pengujian viabilitas dan kinerja mikroba nitrifikasi, dan skala pilot untuk pengujian beban laju alir \& amonia. Modifikasi desain MBBR dan media dari LopezPonnada et al.(2017).

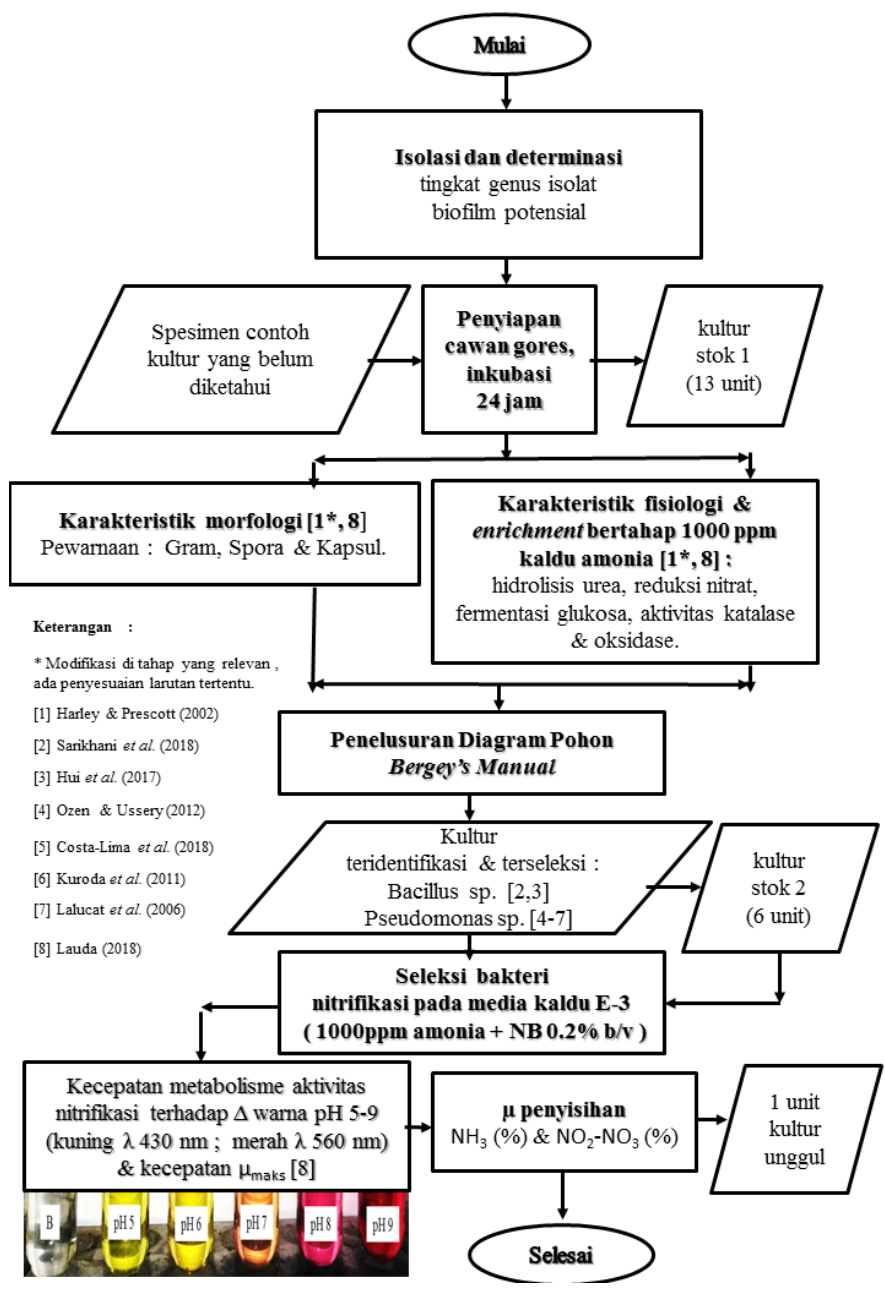

Gambar 2. Skema tahapan isolasi dan seleksi isolat bakteri biofilm indigenous hingga mendapatkan isolat unggul bakteri nitrifikasi indigenous 
Hasil isolat yang mampu bertahan dalam proses seleksi media spesifik kaldu amonia, dilakukan identifikasi tingkat genus menggunakan kunci determinasi Bergey's Manual, sehingga diperoleh 6 kultur isolat potensial nitrifikasi yang merupakan campuran konsorsium dari Bacillus sp. dan Pseudomonas sp.

Isolat terpilih dari kultur stok 2, diuji untuk memilih isolat bakteri nitrifikasi indigenousyang unggul berdasarkan kemampuan viabilitas untuk mendapatkan $\mu_{\text {maks }}$ (Diduch et al,. 2016; Welch et al., 2012; dan Biesta-Peters et al., 2009), pembentukan kapsul/film (Harley dan Prescott, 2002), penempelan biofilm menggunakan SEM (Azeredo et al., 2016 dan Goldstein et al., 1992), kecepatan laju pertumbuhan maksimum mengacu penelitian Stanbury dan Whitaker (1984), kemampuan oksidasi amonia dan kemampuan nitrifikasi. Karakterisasi juga dilakukan secara paralel untuk mengidentifikasi isolat indigenous biofilm sampai tingkat genus mengacu pada metode Bergey's Manual Determinative Bacteriology yang dikembangkan oleh penelitian Harley dan Prescott (2002) menggunakan pendekatan karakteristik morfologi (bentuk sel : cocci/rods; jenis Gram: positif/negatif; kemampuan pembentukan spora hingga kapsul) dan karakteristik kemampuan fisiologi/biokimiawi (produksi enzim pereduksi nitrat/nitrate reductase; kemampuan fermentasi glukosa: positif/negatif terbentuknya asam; kemampuan produksi urease).

\section{Pemanfaatan Isolat Nitrifying Bakteri Biofilm Unggul}

Isolat nitrifying bakteri biofilm unggul yang terpilih pada tahapan sebelumnya, dikembangkan menjadi starter cair untuk dimanfaatkan dalam tahapan pengujian beban laju alir dan beban. Starter cair yang dikembangkan dibuat menggunakan parameter optical density (OD) menggunakan panjang gelombang puncak $430 \mathrm{~nm}$ dan $560 \mathrm{~nm}$ untuk membuat kurva turbiditas. Starter cair siap dipanen saat kecepatan pertumbuhan spesifik maksimum $\left(\mu_{\text {maks }}\right)$ tercapai. Penyiapan starter cair ini bertujuan untuk menyiapkan inokulum aktif yang akan memberikan fase adaptasi/lag yang pendek untuk proses pembebanan biofiltrasi. Media pertumbuhan yang digunakan adalah kaldu amonia dari $\mathrm{NH}_{4} \mathrm{Cl}$ broth. Jumlah inokulum isolat bakteri nitrifikasi indigenous (kode I-12) yang ditambahkan saat kondisi $\mu_{\text {maks }}$ mencapai $1,7 \times 10^{8} \mathrm{CFU} / \mathrm{mL}$.
Inokulum tersebut ditambahkan ke dalam reaktor MBBR sebanyak 1\% (v/v) dari volume total reaktor sehingga konsentrasi bakteri unggul pada MBBR sebesar $10^{6} \mathrm{CFU} / \mathrm{mL}$.

\section{Pengujian Beban Laju Alir, Substrat dan Pemodelan Kinetika Pembebanan}

Pembebanan laju alir dilakukan dengan menambahkan starter cair biofilm unggul kemudian dilakukan pengaturan Hydrolic Retention Time (HRT) untuk volume reaktor biofilter sebanyak 6000 $\mathrm{mL}$, yang divariasikan pada masing-masing aliran reaktor biofilter yaitu selama 1, 2, dan 3 jam dengan laju alir inlet yang digunakan $100 \mathrm{~mL} /$ menit, 50 $\mathrm{mL} / \mathrm{menit}$ dan $34 \mathrm{~mL} / \mathrm{menit}$. Analisa yang difokuskan meliputi analisa kondisi biologis yaitu laju pertumbuhan spesifik bakteri biofilm $/ \mu$ dan laju dilusi/D (Jannasch, 1969). Penentuan beban laju alir secara ringkas disajikan pada Gambar 3.

Pembebanan substrat (amonia) dilakukan untuk mengetahui kemampuan biofilter dalam menahan tambahan beban berupa amonia yang digunakan sebagai substrat untuk proses nitrifikasi, dalam hal ini penambahan substrat yang spesifik mampu didegradasi oleh konsorsium biofilm. Pembebanan dilakukan ketika masa aklimatisasi sudah steady state. Pengoperasian pembebanan dilaksanakan dengan cara melarutkan substrat yang mengandung komposisi $\mathrm{C}: \mathrm{N}: \mathrm{P}=200: 5: 1$ dicampurkan dalam tangki dosing pump kemudian dialirkan ke saluran umpan air baku yang secara kontinyu mengalir ke reaktor MBBR. Perhitungan $\mathrm{C}: \mathrm{N}: \mathrm{P}$ diwakili oleh nilai COD (sebagai C), amonia (N) dan fosfat (P) untuk penyesuaian kebutuhan substrat bakteri kemo-heterotrof maupun kemoautotrof yang berperan pada proses nitrifikasi (Gambar 3).

Level pembebanan amonia di inlet yang dilakukan secara berturut $0,10,20,30 \mathrm{mg} \mathrm{NH} / \mathrm{L}$ hingga dicapai efisiensi penyisihan beban amonia berada dibawah 50\%. Pemodelan kinetika pembebanan untuk proses biologis menggunakan reaksi orde pertama (Tcnobaloglos et al., 2014). Persamaan kinetika disajikan menggunakan perhitungan laju perubahan konsentrasi (C) per satuan waktu $\left(\mathrm{r}_{\mathrm{c}}=\frac{d \mathrm{C}}{d t}=-k C\right)$. Penguraian persamaan kinetika reaksi untuk perhitungan kinetika laju reaksi penyisihan amonia, dapat disederhanakan sebagai berikut:

$$
\begin{aligned}
& \mathrm{r}_{\mathrm{C}}=\frac{d \mathrm{C}}{d t}=-k C \\
& \int \frac{d C}{C}=-\mathrm{k} \int d t \\
& \mathrm{k}=(\mathrm{Q} / \mathrm{V}) \ln \left(\mathrm{C}_{\text {in }} / \mathrm{C}_{\text {out }}\right) \text { dengan } \mathrm{t}=\mathrm{V} / \mathrm{Q} ; \mathrm{V} \text { : volume reaktor } \mathrm{Q} \text { : debit } \\
& C_{C 0}^{C}=-k\left(t_{0}^{t}\right) \\
& \ln \mathrm{C}-\ln \mathrm{C}_{0}=-\mathrm{k}(\mathrm{t}) \text {. }
\end{aligned}
$$




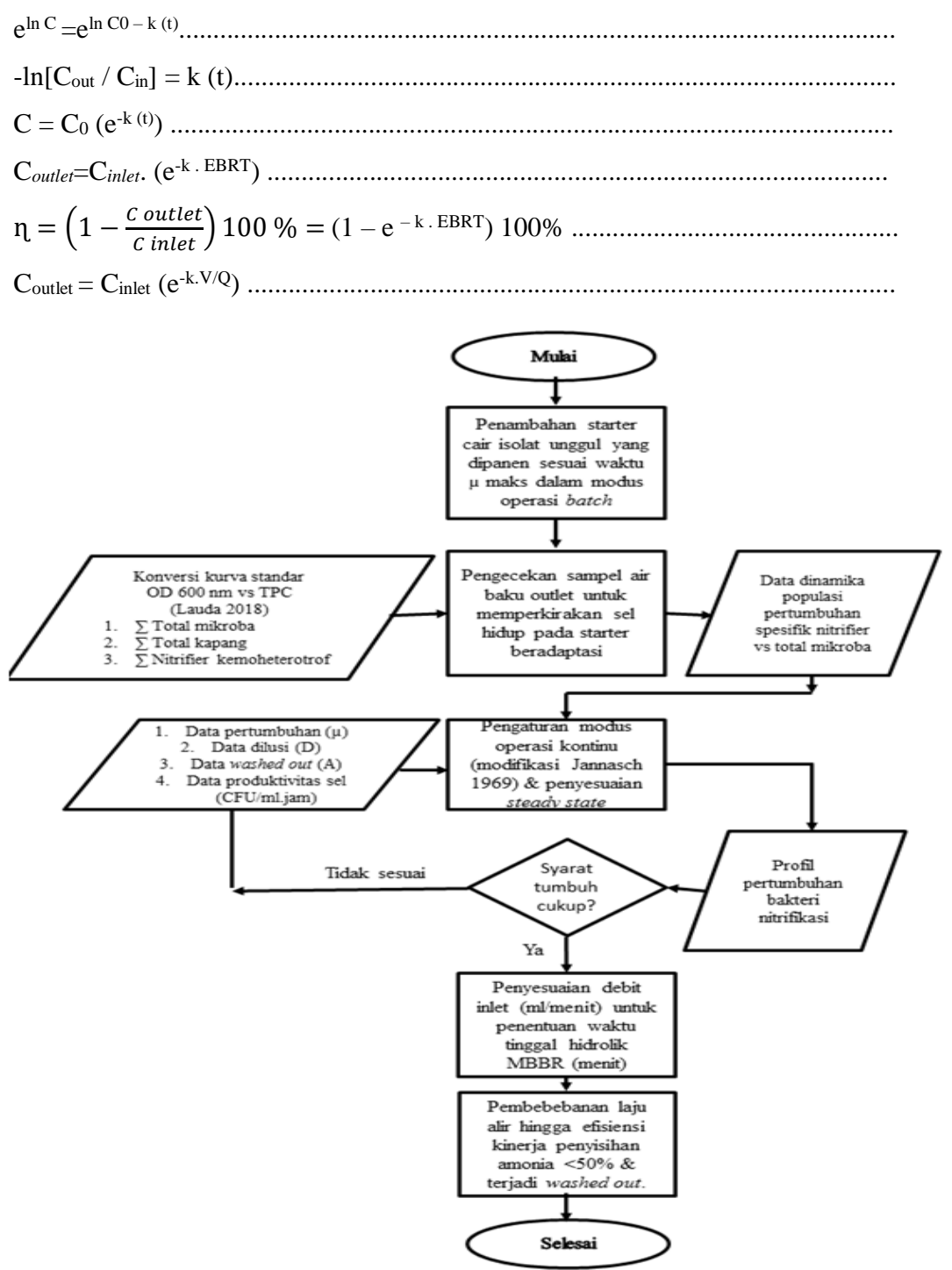

(a)

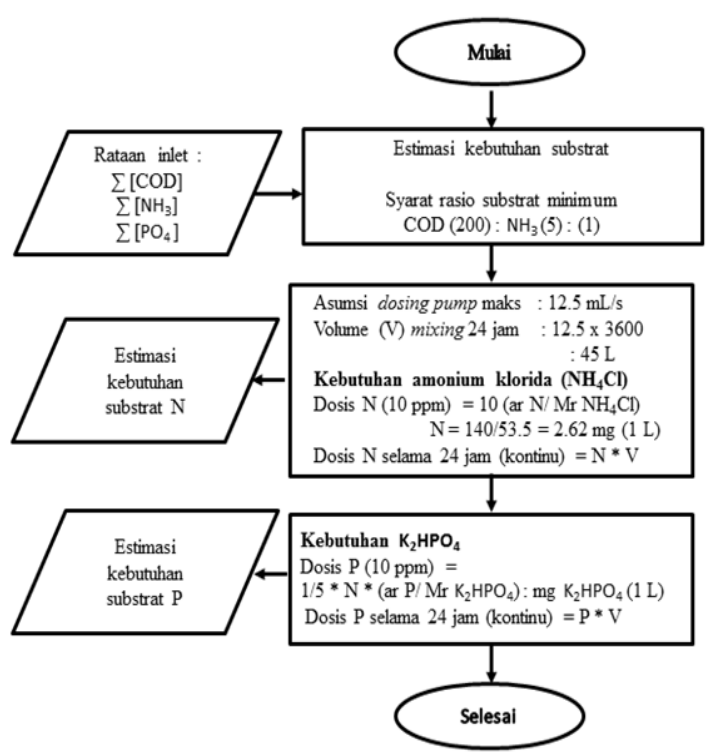

(b)

Gambar 3. Skema penyiapan uji pembebanan laju alir (a) dan kebutuhan substrat amonia (b) 


\section{HASIL DAN PEMBAHASAN}

\section{Karakteristik Air Baku untuk Perancangan Reaktor Biofilter MBBR}

Karakterisasi kualitas air baku pada musim kemarau dan hujan mempengaruhi fluktuasi kualitas air baku. Karakterisasi kontaminan kimia (Tabel 1) dalam air ditunjukkan dengan menentukan kualitas mutu air baku yang mencakup pengukuran bahan kimia agregat (bahan organik, senyawa nitrogen). Kondisi kualitas air baku saat musim hujan mengalami penurunan kualitas, nilai COD pada kedua musim tersebut melebihi ambang baku mutu yang mengindikasikan bahwa kandungan bahan organik masih tinggi.

Shafi et al.(2013) melaporkan sebagian kecil mikroorganisme yang dapat hidup di air tergolong jenis patogen/menyebabkan penyakit pada manusia. Bakteri patogen penting yang dijadikan parameter standar pada air dalam penelitian ini adalah Salmonella sp. Dantotal koliform. Hasil kontaminan mikrobiologis terdeteksi 7 CFU/100 mL untuk total koliform sehingga masih aman dari standar baku mutu yang ditetapkan. Peningkatan populasi Salmonella sp. sebesar $200 \mathrm{CFU} / \mathrm{mL}$ erat kaitan dengan kondisi rasio substrat dalam air baku yaitu rasio COD : $\mathrm{NH}_{3}: \mathrm{PO}_{4}$ sebesar 110: 0,140 : 5,74 yang menunjukkan konsentrasi fosfor berlebih lima kali lipat dari kebutuhan minimumnya mikroba untuk hidup dimana memerlukan rasio $\mathrm{COD}: \mathrm{NH}_{3}$ : $\mathrm{PO}_{4}$ sebesar 100:5:1 (modifikasi Krishnan et al., 2008). Kondisi karakteristik kualitas air baku yang belum memenuhi standar yang ditentukan dari ketiga aspek kontaminan fisik, kimia dan mikrobiologi memerlukan strategi pengelolaan mutu air baku agar tidak menjadi beban operasi dalam instalasi pengelolaan air bersih. Oleh karena itu, pada studi kasus penelitian yang ini kondisi air mutu air baku harus berhubungan dengan kondisi bahan organik termasuk didalamnya substrat organik (Gambar 3) dan mikroba tertentu untuk mengoptimalkan proses pendegradasian kontamian kimia berbahaya seperti COD, amonia, dan nitrat (Tabel 1).

\section{Karakteristik Isolat Bakteri Nitrifikasi Indigenous Biofilm \\ Penggunaan starter isolat biofilm} indigenous unggul bermanfaat untuk mempercepat fase adaptasi biofilm dan meningkatkan peforma dalam proses nitrifikasi. Hasil isolasi diperoleh sebanyak 13 koloni isolat yang dominanjenis bakteri (Gambar 2). Kemudian secara bertahap diseleksi pada media $\mathrm{NH}_{4} \mathrm{Cl}$ dan kaldu Nutrient Broth (Oxoid) sehingga diperoleh enam isolat bakteri yang potensial (Tabel 2). Keenam isolat tersebut dilakukan karakterisasi untuk memperoleh isolat bakteri nitrifikasi unggul yang berpotensi dikembangkan menjadi starter cair.

Keseluruhan isolat dilakukan identifikasi sampai tingkat genus menunjukkan mengandung dua jenis strain bakteri yaitu strain Bacillus sp. yang merupakan jenis bakteri Gram positif berbentuk batang/rods dan mampu menghasilkan spora, serta strain Pseudomonas sp. merupakan jenis bakteri Gram negatif berbentuk batang/rods, tidak mampu memfermentasi glukosa serta positif menghasilkan enzim urease yang berguna dalam mendegradasi urea menjadi nitrat (Harley dan Prescott, 2002).

Tabel 2 menunjukkan dua isolat yang memenuhi seluruh kriteria isolat biofilm unggul yaitu I-03 dari matriks filter Bioball/PVC dan I-12 PET chips. Berdasarkan aspek viabilitas, laju pertumbuhan maksimum ( $\mu$ maks), dan kemampuan eliminasi amonia isolat I-12 secara relatif lebih unggul dibandingkan isolat I-03. Maka isolat I-12 terpilih untuk diperbanyak menjadi starter cair.

\section{Pemanfaatan Isolat Unggul \\ Kurva pertumbuhan bakteri nitrifikasi indigenous unggul dilakukan dengan mengukur turbiditas kultur (Gambar 4) untuk menentukan fase eksponensial bakteri biofilm. Bakteri biofilm mencapai kecepatan spesifik maksimum $\left(\mu_{\text {maks }}\right)$ pada jam ke-6. Bakteri biofilm masih berada pada fase lag pada jam ke-0 hingga jam ke-3. Bakteri biofilm berada pada fase eksponensial setelah jam ke-4 hingga jam ke-7 dan memasuki fase stasioner setelah jam ke-8. Dalam penyiapan starter isolat akan ditumbuhkan dan diinokulasikan pada jam ke-6.}

Tabel 1. Pengaruh musim terhadap kualitas intake air baku mengacu pada standar baku mutu kualitas air baku (PPRI, 2001).

\begin{tabular}{lcccc}
\hline Jenis Kontaminan & $\begin{array}{c}\text { Musim } \\
\text { Kemarau }\end{array}$ & $\begin{array}{c}\text { Musim } \\
\text { Hujan }\end{array}$ & $\begin{array}{c}\text { Baku Mutu } \\
\text { Kelas 1 }\end{array}$ & $\begin{array}{c}\text { Baku Mutu } \\
\text { Kelas 2 }\end{array}$ \\
\hline a. Kontaminan Kimia : & & & & 25 \\
COD (mg/L) & 90 & 110 & 10 & - \\
Amonia (mg/L) & $<0,140$ & 0,140 & 0,5 & 10 \\
Nitrat $(\mathrm{mg} / \mathrm{L})$ & 0,370 & 28,08 & 10 & 0,2 \\
Fosfat (mg/L) & 0,149 & 5,74 & 0,2 & 0 \\
b. Kontaminan Mikrobiologis : & & & & 5000 \\
Salmonella sp.(CFU/mL) & 0 & 200 & 0 & 1000 \\
Total Koliform $(\mathrm{CFU} / 100 \mathrm{~mL})$ & 7 & 1100 & & 5 \\
\hline
\end{tabular}


Tabel 2. Hasil karakterisasiisolat bakteri nitrifikasi indigenous biofilm unggul serta kemampuan fisiologi/biokimiawi (produksi enzim nitrate reductase)

\begin{tabular}{|c|c|c|c|c|c|c|c|}
\hline $\begin{array}{c}\text { Isolat } \\
\text { Bakteri }\end{array}$ & $\begin{array}{c}\text { Viabilitas } \\
\text { Isolat 72jam } \\
(\mathrm{Cfu} / \mathrm{mL})\end{array}$ & $\begin{array}{l}\mathrm{pH} \\
72 \mathrm{~h}\end{array}$ & $\begin{array}{c}\mu \mathrm{maks} \\
(/ \mathbf{j a m})\end{array}$ & $\begin{array}{c}\text { Pembentukan } \\
\text { Kapsul }\end{array}$ & $\begin{array}{c}\text { Nitrate } \\
\text { Reductase }\end{array}$ & $\begin{array}{c}\text { Eliminasi } \\
\text { ammonia } \\
{\left[\mathrm{NH}_{4}\right]} \\
\%\end{array}$ & $\begin{array}{c}\text { Elimasi } \\
\text { Nitrit- } \\
\text { Nitrat } \\
\%\end{array}$ \\
\hline I-01 & $2,10 \times 10^{20}$ & 8,22 & 0,1396 & + & - & 17,50 & 98,45 \\
\hline $\mathrm{I}-02$ & $2,40 \times 10^{19}$ & 8,00 & 0,1051 & + & - & 18,89 & 94,73 \\
\hline I- 03 & $1,51 \times 10^{20}$ & 7,94 & 0,0503 & ++ & + & 27,78 & 97,82 \\
\hline I-05 & $9,30 \times 10^{19}$ & 8,21 & 0,0965 & + & - & 8,33 & 97,71 \\
\hline I-10 & $2,50 \times 10^{20}$ & 8,19 & 0,0775 & + & - & 30,56 & 97,72 \\
\hline $1-12$ & $2,50 \times 10^{20}$ & 8,21 & 0,0970 & ++ & + & 30,56 & 97,32 \\
\hline
\end{tabular}

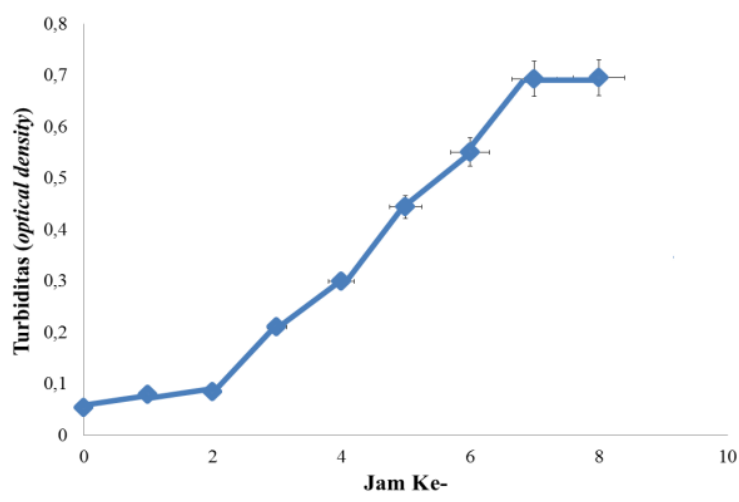

Gambar 4. Kurva turbiditas bakteri nitrifikasi indigenous isolat I-12

\section{Penentuan Beban Laju Alir}

Fenomena washout yaitu tercucinya sel bakteri dari matriks biofilm akibat variasi HRT akan berdampak pada kestabilan dari sistem biofilter dalam mempertahankan kondisi steady state-nya. Kestabilan pertumbuhan konsorsium biofilm unggul yang ditambahkan, dalam mempertahankan fase steady state saat diberikan beban variasi laju alir inlet secara kontinu (Gambar 5).

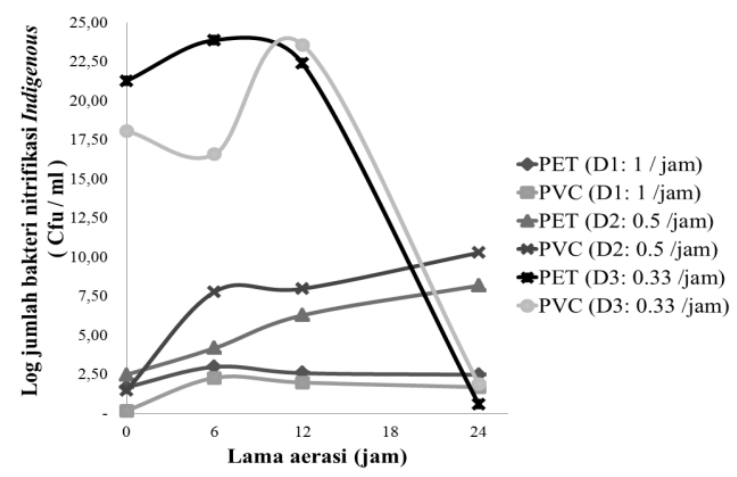

Gambar 5. Pengaruh pembebanan laju alir terhadap profil kecepatan pertumbuhan spesifik bakteri biofilm indigenous pengoksidasi amonia $(\mathrm{Cfu} / \mathrm{mL})$ terhadap laju dilusi $\left(\mathrm{D}-\mathrm{jam}^{-1}\right)$

\section{Penentuan Beban Substrat Amonia}

Simulasi pembebanan amonia sebagai substrat sumber nitrogen pada proses nitrifikasi dilakukan untuk mengukur kinetika variabel inlet dan outlet pada proses biofiltrasi secara aerobik dengan mengkondisikan HRT selama 2 jam. Kurva hubungan linier dari konsentrasi $\mathrm{C}_{\text {inlet }}$ dan $\mathrm{C}_{\text {outlet }}$ (Gambar 6a) pada konsentrasi 0-30 $\mathrm{mg} / \mathrm{L}$ menghasilkan persamaan liniear $\mathrm{Y}_{\mathrm{PET}}=0,703 \mathrm{x}$ dengan koefisien korelasi 0,880 , sedangkan $\mathrm{Y}_{\mathrm{PVC}}=$ $0,751 \mathrm{x}$ dengan koefisien korelasi 0,963 . Deteksi perkiraan laju reaksi penyisihan amonia oleh starter bakteri nitrifikasi indigenous unggul (Bacillus sp. dan Pseudomonas sp.) memiliki selektivitas dan kecermatan deteksi yang cukup baik pada rentang 0 $30 \mathrm{mg} / \mathrm{L}$.

Biofilter MBBR menunjukkan adanya peningkatan efisiensi dari penambahan amonia 10 $\mathrm{mg} / \mathrm{L}$ dan starter bakteri nitrifikasi indigenous (Gambar 6b) sebesar 49,94\% menjadi 57,19\% untuk PET chips, sedangkan untuk PVC menurun dari $49,94 \%$ menjadi $47,27 \%$. Selanjutnya pada peningkatan konsentrasi $20 \mathrm{mg} / \mathrm{L}$ hingga $30 \mathrm{mg} / \mathrm{L}$, PET chips mampu menyisihkan amonia 48,51\% menjadi $18,50 \%$, sedangkan untuk PVC mampu menyisihkan amonia $33,90 \%$ menjadi $18,89 \%$. Persamaan linieritas yang dihasilkan menunjukkan kesesuaian pola laju reaksi orde satu (Tchnobanoglous et al., 2014) yang berlaku pada tingkat pembebanan amonia pada rentang 1,16 $31,95 \mathrm{mg} / \mathrm{L}$. Berdasarkan performa dalam mempertahankan steady state pertumbuhan bakteri nitrifikasi terjaga saat konsentrasi inlet $20 \mathrm{mg} / \mathrm{L}$ (Gambar 6b).

Kestabilan fase steady state pada biofilter MBBR PET chips $(\Delta), \operatorname{PVC}(\mathrm{x})$ berhasil dicapai pada tingkat HRT 2 jam dengan laju dilusi sebesar 0,5 $\mathrm{jam}^{-1}($ Gambar 7a) yang ditandakan dari kestabilan konsorsium biofilm unggul mempertahankan fase stationer-nya/kondisi steady-state, dimana jumlah bakteri heterotrof (Bacillus sp. dan Pseudomonas sp.) hidup sebanding dengan jumlah bakteri heterotrof yang mati dan ikut tercuci keluar (laju washout) dari sistem biofilter MBBR (Gambar 7b). 


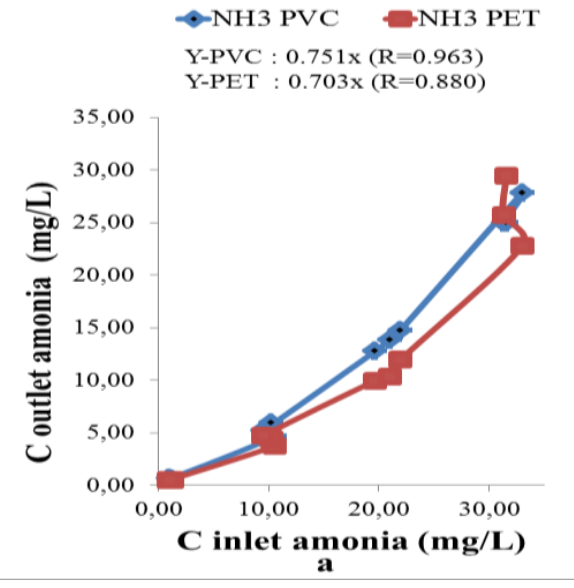

Gambar 6. Kurva pengaruh peningkatan beban amonia pada (a) inlet terhadap konsentrasi amonia pada outletMBBR; (b) laju penyisihan amonia MBBR
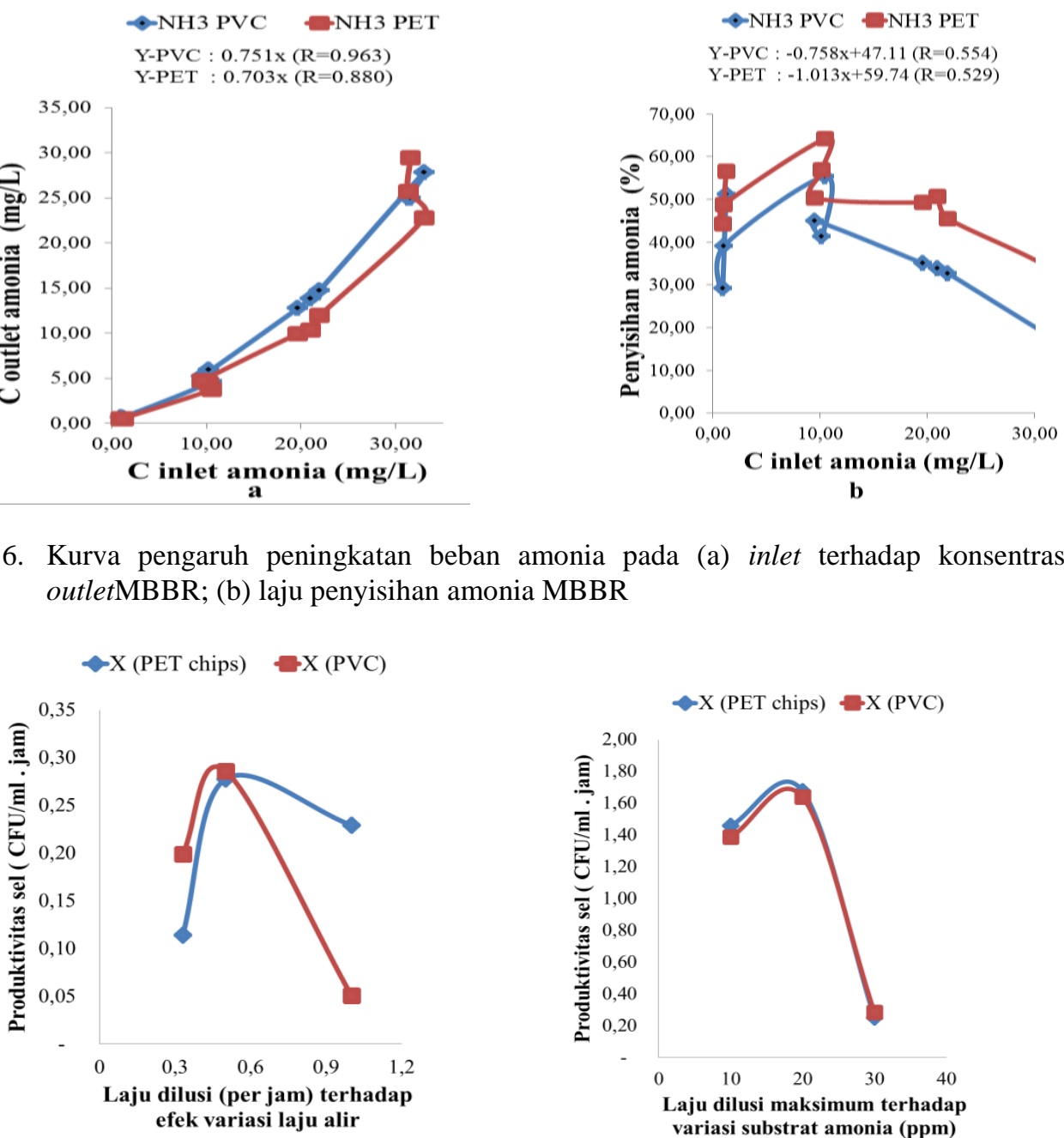

a.

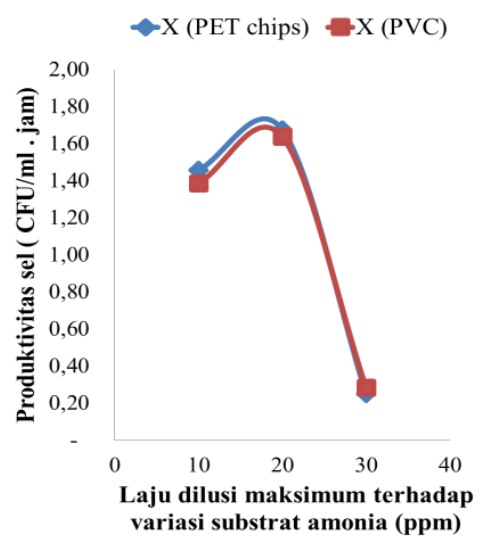

b.

Gambar 7. Efek laju dilusi maksimum $\left(\mathrm{D}_{\text {maks }}=0.5 / \mathrm{jam}\right)$ dan peristiwa pencucian sel biofilm / washout(A) terhadap profil produktivitas sel biofilm maksimum (DX) : (a). Perlakuan laju alir untuk menentukan $\mathrm{D}_{\text {maks, }}$, dan (b). Perlakuan konsentrasi umpan amonia di inlet

\section{Pemodelan Kinetika Pembebanan Amonia}

Konstanta kinetika yang dihasilkan untuk laju reaksi penyisihan amonia dengan penambahan starter mengikuti Persamaan (7). Nilai dari konstanta kinetika diplotkan seperti pada Gambar 8a, berturut adalah $\mathrm{k}_{\mathrm{PET}}: 0,421 \mathrm{jam}^{-1}$ dan $\mathrm{k}_{\mathrm{PVC}}: 0,412$ $\mathrm{jam}^{-1}$. Nilai konstanta laju penyisihan (k) yang dihasilkan mampu menunjukan perbaikan kinerja penyisihan amonia dibandingkan tanpa penambahan starter bakteri nitrifikasi biofilm unggul, dimana nilai konstanta penyisihan ammonia tanpa penambahan starter adalah $\mathrm{kPET}_{\mathrm{PET}}$ : $0,153 \mathrm{jam}^{-1}$ (Kertasana, 2017), sedangkan pada kPVC: $0,358 \mathrm{jam}^{-1}$ (Syarif, 2017). Efisiensi penyisihan kinetika amonia (Persamaan 10) untuk PET adalah 62,47\% dan PVC adalah $58,80 \%$. Hasil dari persamaan 10, digunakan untuk pengembangan model kinetika penyisihan amonia (Gambar 8b) untuk biofilter tipe MBBR jenis PET chips dan PVC untuk memperkirakan konsentrasi outlet amonia yang sesuai dengan kriteria mutu air baku diatur (PPRI, 2001)
Model kinetika yang diperoleh hanya signifikan pada kondisi Empty Bed Biofilter Reactor/EBRT yaitu 1-7 jam. Kelebihan dari penelitian ini dibandingkan dengan penelitian sebelumnya (Kertasana, 2017; Salas, 2016; Syarif ,2017; Widayat, 2010) adalah penggunaan starter isolat bakteri nitrifikasi indigenous kelompok heterotrof, dapat meningkatkan eliminasi amonia pada air baku. Penggunaan model kinetika eliminasi amonia (Gambar 8) dapat diaplikasikan untuk kebutuhan scale up instalasi reaktor MBBR, dibantukan dengan mengubah perbandingan volume kerja $(\mathrm{V})$ dengan debit reaktor $(\mathrm{Q})$ dari penurunan rumus matematik mengikuti Persamaan 10 menjadi seperti pada Persamaan 11. Disamping itu, perlu ditetapkan tingkat kualitas air baku yang diinginkan

$\mathrm{C}_{\text {outlet }}=\mathrm{C}_{\text {inlet }} \cdot \mathrm{e}^{-\mathrm{k} V / Q}$ 


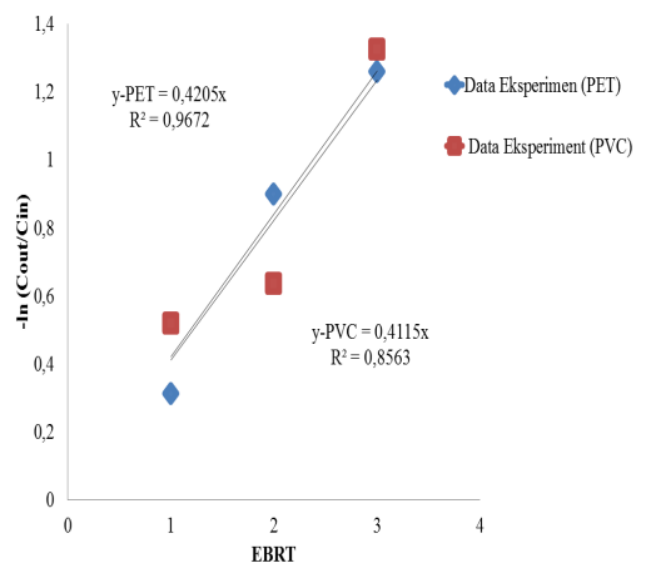

(a)

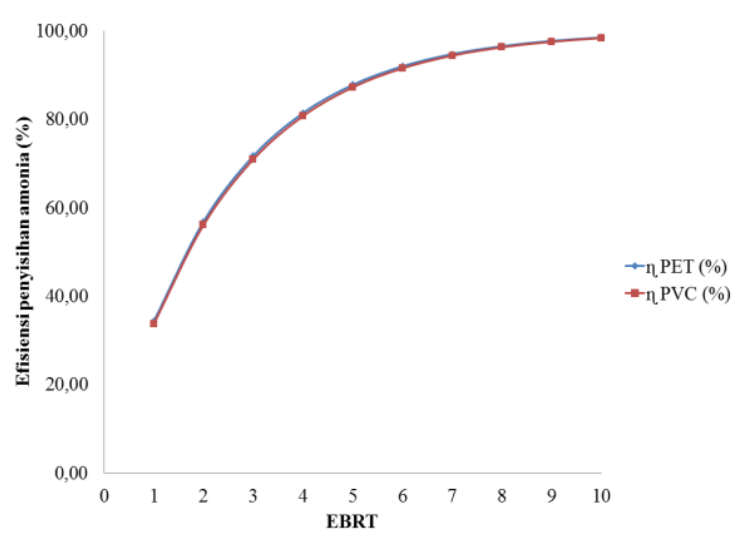

(b)

Gambar 8. Hasil pemodelan kinetika pembebanan dengan penambahan starter nitrifikasi unggul dari indigenous biofilm: (a) data mengikuti persamaan kinetika orde 1, dan (b) perkiraan efisiensi penyisihan amonia

\section{KESIMPULAN DAN SARAN}

\section{Kesimpulan}

Isolat konsorsium biofilm unggul dalam penyisihan amonia teridentifikasi sebagai kelompok bakteri heterotrof yaitu Bacillus sp. dan Pseudomonas sp yang berhasil diseleksi dari 13 koloni isolat indigenous biofilm yang ditumbuhkan secara spontan (inkubasi $24 \mathrm{jam}, 37^{\circ} \mathrm{C}$ ).

Starter isolat biofilm unggul dalam penyisihan amonia berhasil memperbaiki kinerja proses biofiltrasi air baku terhadap kondisi beban amonia (tanpa starter), mengikuti profil model kinetika orde 1 yaitu $\mathrm{C}_{\text {out }}=\mathrm{C}_{\text {in }} \exp (-\mathrm{k} . E B R T)$. Sehingga dapat digunakan sebagai dasar desain estimasi kebutuhan operasi scale up instalasi reaktor MBBR dengan mengubah perbandingan volume kerja (V) dengan debit reaktor (Q).

Konstanta kinetika penyisihan amonia pada masing reaktor MBBR yang telah diberikan starter secara berturut : (1) $\mathrm{k}_{\mathrm{PET}}=0,421 \mathrm{jam}^{-1}(\eta=62,47 \%$ $\left.\mathrm{NH}_{3}\right)$ and (2) $\mathrm{kPVC}_{\mathrm{PV}}=0,412 \mathrm{jam}^{-1}\left(\eta=58,80 \%-\mathrm{NH}_{3}\right)$ yang memiliki nilai efisiensi lebih baik daripada yang tanpa perlakuan starter biofilm unggul.

\section{Saran}

Terkait perbaikan untuk penelitian berikutnya, dapat dikaji interaksi dari peranan kelompok bakteri nitrifikasi kelompok autrotrof (Nitrosomonas sp., Nitrobacter sp.) dan kelompok bakteri pendegradasi fosfat, kemampuan pembentukan film secara kuantitatif (Exo-polysaccharides/EPS), kemampuan pembentukan kapsul secara kuantitatif, pengaruh efek penambahan isolat bakteri nitrifikasi indigenous terhadap eliminasi COD, nitrat dan fosfat serta identifikasi isolat bakteri nitrifikasi biofilm unggul hingga tingkat spesies menggunakan analisis molekular (DNA).

\section{DAFTAR PUSTAKA}

[APHA] American Public Health Association. 2012. Standard methods for examination of water and wastewater, $22^{\text {nd }} E d$. Washington DC (US): APHA.

Azeredo J, Azevedo NF, Briandet R, Cerca N, Coenye $\mathrm{T}$, Costa AR, Desvaux $\mathrm{M}$, Bonaventura GD, Hebraud M, Jaglic Z, et al. 2016. Critical review on biofilm methods. Crit Rev Microbiol.43(3):313-351, doi 10.1080/1040841X.2016.1208146.

Biesta-Peters EG, Reiji MW, Joosten H, Gorris LGM, Zwietering MH. 2009. Comparison of two optical density based methods and plate count method for estimation of growth parameters of Bacillus cereus. Journal Appl Environ Microbiol.76(5):1399-1405, doi 10.1128/AEM.02336-09.

Burrel PC, Phalen CM, Hovanec TA. 2001. Identification of bacteria responsible for amonia oxidation in freshwater aquaria. Journal Appl Environ Microbiol. 67(12):5791-5800, doi 10.1128/AEM. 67.12.5791-5800.2001.

[BPS] Badan Pusat Statistik. 2017. Survei Sosial Ekonomi. Jakarta (ID) : BPS.

Costa-Lima JJ, Alves LR, Jacome PRLA, Neto JPB, Maciel MAV, Morais MMC. 2018. Biofilm production by clinical isolates of Pseudomonas aeruginosa and structural changes in LasR protein of isolates non biofilm-producing. Elsevier. Braz Journal Infct Dis, doi : 10.1016/j.bjid. 2018. 03, 003.

Diduch M, Polkowska Z, dan Namiesnik. 2016. The role of heterotrophic plate count bacteria in bottled water quality assesment. Journal Food Cont. 61:188-195, doi 10.1016/ j.foodcont.2015.09.024.

Goldstein JI, Newbury DE, Echlin P, Joy DC, Ronsig AD. Jr, Lyman CE, Fiori C, Lifshin 
E. 1992. Scanning Electron Microscopy and X-ray Microanalysis: A Text for Biologist, Material Scientist and Cytologists $2^{\text {nd }} E d$. New York (US): Plemun Press.

Harley JP dan Prescott LM. 2002. Laboratory Exercises in Microbiology (Fifth edition). New York (US): The McGraw-Hill Companies.

Hui C, Guo X, Sun P, Khan RA, Zhang Q, Liang Y, Zhao YH. 2017. Removal of nitrite from aquous solution by Bacillus amyloliquefaciens biofilm adsorption. Journal Bioresour Technol. 1-20.

Jannasch HW. 1969. Estimations of bacterial growth rates in natural water. Journal Bacteriol.99(1):156-160.

Kertasana H. 2017. Kinerja proses biofiltasi media potongan botol bekas AMDK dalam penyisihan amonium. [skripsi]. Bogor (ID): Institut Pertanian Bogor.

Krishnan V, Ahmad D, dan Jeru JB. 2008. Technical note influence of COD : $\mathrm{N}$ : $\mathrm{P}$ ratio dark greywater treatment using a sequencing batch reactor. Journal Chem Technol Biotechnol. 83(5):756-762, doi 10.1002/jctb.1842.

Kuroda M, Notaguchi E, Sato A, Yoshioka M, Hasegawa A, Kagami T, Narita T, Yamashita M, Sei K, Soda S, Ike M. 2011. Characterization of Pseudomonas stuzuri NT-1 capable of removing soluble selenium from the aquous phase under aerobic condition. Journal Biosci Bioeng. 112(3) : 259-264.

Lalucat J, Bennasar A, Bosch R, Garcia-Valdes E, Palleroni NJ. 2006. Biology of Pseudomonas stutzeri. Journal Microbiol Mol Bio Rev. 70 (2) : 510-547.

Lauda RD. 2018. Perbaikan kualitas air baku oleh isolat bakteri nitrifikasi indigenous menggunakan moving bed biofilter reactor (MBBR). [Tesis]. Bogor (ID) : Institut Pertanian Bogor.

Lopez-Ponnada EV, Lynn TJ, Peterson M, Ergas SJ, Michelcic JR. 2017. Application of denitrifying wood chip bioreactors for management of residential non-point sources of nitrogen. Journal Biol Eng. 11(16):1-14, doi 10.1186/s13036-017-0057-4.

Ozen AI dan Usserry DW. 2012. Defining the Pseudomonas genus : where do we draw line with Azetobacter. Journal Microb Ecol. 63 : 239-248.

[PPRI] Peraturan Pemerintah Republik Indonesia No. 82 Tahun 2001 tentang Pengelolaan Kualitas Air dan Pengendalian Pencemaran Lingkungan. Jakarta (ID): PPRI.
[PPRI] Peraturan Pemerintah Republik Indonesia No. 122 Tahun 2015 tentang Sistem Penyediaan Air Minum. Jakarta (ID): PPRI.

Salas AA. 2016. Penurunan bahan polutan air baku menggunakan biofiltrasi dengan media potongan bekas botol kemasan air minum. [skripsi]. Bogor (ID): Institut Pertanian Bogor.

Sarikhani M, Kermanshahi RK, Ghadam P, Gharavi S. 2018. The role of prebiotic Lactobacillus acidophilus ATCC 4356 Bacteriocin on effect of Hbsu on planktonic cells and biofilm formation of Bacillus subtilis. Journal Bio Mac. BIOMAC 9309. Iran, doi : 10.1016/j.ijbiomac.2018.03.087.

Shafi S, Kamili AN, Shah MA, Bandh SA. 2013. Coliform bacterial estimation: a tool for assessing water quality of Manasbal Lake of Kashmir, Himalaya. Afr. Journal Microbiol Res. 7 (31):3996-4000, doi 10.5897/ AJMR2013.5863.

Stanbury PF dan Whitaker A. 1984. Principles of Fermentation Technology. Oxford (UK): Pergamon Press.

Spigno G, Pagella C, Fumi MD, Molteni R, De Faveri DM. 2003. VOC removal from waste gases: gas-phase bioreactor for the abatement of hexane by Aspergillus niger. Journal Chem Eng Sci. 58:739-746, doi 10.1016/S0009-2509(02)00603-6.

Suprihatin, Romli M, Yusuf MA, Putri BC. 2013. Quality improvement and quality fluctuations equalization of raw water for drinking water supply by using a packed bed bioreactor. Proceeding of $2^{\text {nd }}$ International Conference on Adaptive and Intelligent Agroindustry 2013. Bogor (ID): Institut Pertanian Bogor. 16-17 September 2013.

Syarif RI. 2017. Pemodelan kinetika penyisihan amonium pada reaktor biofilter media bioball dengan pendekatan empiris. [skripsi]. Bogor (ID): Institut Pertanian Bogor.

Tchnobanoglous G, Stensel HD, Tsuchihashi R, Burton F. 2014. Wastewater Engineering Treatment and Resource Recovery (5 $5^{\text {th }}$ $E d)$.New York (USA): Metcalf \& Eddy. McGraw-Hill Education. NY.

Welch K, Cai Yanling, dan Maria S. 2012. A method for quantitative determination of biofilm viability. Journal Func Biomater.3 (2) :418-431, doi 10.3390/jfb3020418.

Widayat W. 2010. Peningkatan kualitas air baku perusahaan air minum dengan proses biofiltrasi menggunakan media plastik tipe sarang tawon. [Tesis]. Bogor (ID) : Institut Pertanian Bogor. 